\title{
Children as Caregivers
}

sacs 


\section{The Rutgers Series in Childhood Studies}

The Rutgers Series in Childhood Studies is dedicated to increasing our understanding of children and childhoods throughout the world, reflecting a perspective that highlights cultural dimensions of the human experience. The books in this series are intended for students, scholars, practitioners, and those who formulate policies that affect children's everyday lives and futures.

Edited by Myra Bluebond-Langner, Board of Governors Professor of Anthropology, Rutgers University, and True Colours Chair in Palliative Care for Children and Young People, University College London, Institute of Child Health

\section{Advisory Board}

Perri Klass, New York University

Jill Korbin, Case Western Reserve University

Bambi Schieffelin, New York University

Enid Schildkraut, American Museum of Natural History and Museum for African Art

For a list of all the titles in the series, please see the last page of the book. 


\title{
Children as Caregivers
}

\author{
经: \\ The GlobaL Fight AGAINST \\ TUBERCULOSIS AND HIV IN ZAMBIA
}

Jean Hunleth

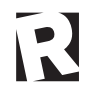

RUTGERS UNIVERSITY PRESS

NEW BRUNSWICK, CAMDEN, AND NEWARK, NEW JERSEY, AND LONDON 
Library of Congress Cataloging-in-Publication Data

Names: Hunleth, Jean, 1976-author.

Title: Children as caregivers : the global fight against tuberculosis and HIV in Zambia / Jean Hunleth.

Other titles: Rutgers series in childhood studies.

Description: New Brunswick, New Jersey : Rutgers University Press, 2017. | Series: Rutgers series in childhood studies

Identifiers: LCCN 2016032166| ISBN 9780813588049 (hardcover : alk. paper) | ISBN 9780813588032 (pbk. : alk. paper) | ISBN 9780813588056 (e-book (epub)) | ISBN 9780813588063 (e-book (web pdf))

Subjects: LCSH: Child caregivers-Zambia. | AIDS (Disease)-Patients-Home care-Zambia. | HIV-positive persons-Home care-Zambia. | TuberculosisPatients-Home care-Zambia.

Classification: LCC HQ759.67 .H86 2017 | DDC 362.1096894-dc23

LC record available at https://lccn.loc.gov/2016032166

A British Cataloging-in-Publication record for this book is available from the British Library.

Copyright (c) 2017 by Jean Hunleth

All rights reserved

No part of this book may be reproduced or utilized in any form or by any means, electronic or mechanical, or by any information storage and retrieval system, without written permission from the publisher. Please contact Rutgers University Press, 106 Somerset Street, New Brunswick, NJ 08901. The only exception to this prohibition is "fair use" as defined by U.S. copyright law.

$\infty$ The paper used in this publication meets the requirements of the American National Standard for Information Sciences-Permanence of Paper for Printed Library Materials, ANSI Z39.48-1992.

www.rutgersuniversitypress.org

Manufactured in the United States of America 
For my parents, Frank and Mary Ann 
